\title{
Serum cytokines in patients with Brazilian pemphigus foliaceus (fogo selvagem)
}

\author{
D.M. Zeoti², \\ J.F.C. Figueiredo ${ }^{1}$, \\ M.P.V. Chiossi2 and \\ A.M.F. Roselino ${ }^{2}$
}

\author{
Divisão de ${ }^{1} \mathrm{M}$ oléstias Infecciosas and ${ }^{2}$ Dermatologia, \\ Departamento de Clínica Médica, \\ Faculdade de Medicina de Ribeirão Preto, \\ Universidade de São Paulo, Ribeirão Preto, SP, Brasil
}

\author{
Correspondence \\ A.M.F. Roselino \\ Divisão de Dermatologia \\ Departamento de Clínica Médica \\ FMRP, USP \\ Av. Bandeirantes, 3900 \\ 14049-900 Ribeirão Preto, SP \\ Brasil \\ Fax: + 55-16-633-0236 \\ E-mail: \\ ana.roselino@ cbrc2.mgh.harvard.edu \\ Research supported partially by \\ FAEPA (Fundação de Amparo ao \\ Ensino, Pesquisa e Assistência, \\ Hospital das Clínicas, Faculdade de \\ Medicina de Ribeirão Preto, USP). \\ Publication supported by FAPESP.
}

Received August 20, 1999 Accepted June 21, 2000

\section{Abstract}

Pemphigus foliaceus (PF) is characterized by acantholysis determined by $\mathrm{IgG}_{4}$ binding to desmoglein $\mathrm{I}$, a $160-\mathrm{kDa}$ desmosomal glycoprotein. To investigate the immunopathological aspects of Brazilian PF, we determined levels of serum cytokines in patients with PF. Twentyfive patients with PF and a control group consisting of 10 healthy individuals were studied. Serum IL-2, IL-4, IL-5, IL-10, IL-12 and IFN- $\gamma$ were measured in the two groups by ELISA. The median concentration of IL-2 was lower in PF patients compared to the control group ( 0.45 and $9.50 \mathrm{pg} / \mathrm{ml}$, respectively), as also was the concentration of IL-4 ( 0.26 and $10.16 \mathrm{pg} / \mathrm{ml}$, respectively). The same was observed for IL-5 (7.94 and $15.74 \mathrm{pg} / \mathrm{ml}$, respectively) and for IFN- $\gamma$ (5.90 and $8.58 \mathrm{pg} / \mathrm{ml}$, respectively). For IL-10 and IL-12, higher concentrations were observed in PF compared to the control group (IL-10: 24.76 and 20.92; IL-12: 2.92 and $1.17 \mathrm{pg} / \mathrm{ml}$, respectively). Considering the $\mathrm{Th} 1 / \mathrm{Th} 2$ paradigm, it seems that a Th2 profile, mainly represented by IL-10, predominates in PF.

\section{Introduction}

In Brazil, the first cases of pemphigus foliaceus (PF) were documented by Aranha Campos in 1860. Its characteristics are similar to those of the nonendemic PF that occurs in North America and Europe, described by Cazenave in 1844 (1).

The immunohistologic mechanism of PF was only recognized in 1964, when Beutner and Jordan (2) demonstrated by immunofluorescence the existence of intercellular $\mathrm{IgG}$ throughout the epidermis. The antibodies observed in $\mathrm{PF}$ are $\mathrm{IgG}_{4}$ that bind to desmoglein
I, a 160-kDa desmosomal glycoprotein $(3,4)$.

The mechanism of acantholysis in PF is not completely understood, and some reports have suggested that the plasminogenplasmin system may be involved in it (5). D'Auria et al. (6) described the participation of interleukin 6 (IL-6) and TNF- $\alpha$ in pemphigus vulgaris. Inaoki and Takehara (7) demonstrated increased serum levels of IL-5, IL6 and IL-8 in patients with bullous pemphigoid.

In the present study we determined serum levels of some cytokines in patients with Brazilian PF. 


\section{Material and Methods}

Twenty-five patients with PF were enrolled in the study before the initiation of treatment. All patients attended the Dermatology clinic of the University Hospital, Faculty of Medicine of Ribeirão Preto, University of São Paulo, Brazil. A control group consisted of 10 healthy individuals. The clinical diagnosis of PF was confirmed by acantholysis in the upper epidermis in skin biopsies. Patients with flaccid bullae and crusts on the head and upper thorax were considered to have localized PF, while those with lesions also in abdomen and limbs were considered to have generalized PF.

Serum IL-2, IL-4, IL-5, IL-10, IL-12 and IFN- $\gamma$ were measured in the individu- als of the two groups by ELISA (R\&D Systems, Minneapolis, MN, USA). For statistical analysis the Mann-Whitney and Fisher tests were used to compare cytokine levels between groups, and cytokine levels between patients with localized or generalized forms of PF.

\section{Results}

Among the patients with $\mathrm{PF}$, age ranged from 10 to 68 years (mean $=30$ ). Fourteen were females, 14 were white, 9 were mulattoes and 2 were black. Eighteen presented the localized form of PF (Table 1).

The median concentrations of IL-2 and IL-4 were lower in PF patients $(\mathrm{P}<0.01)$ compared to controls: 0.45 and $9.50 \mathrm{pg} / \mathrm{ml}$,

Table 1 - Data about patients with pemphigus foliaceus (PF) and their serum concentrations of cytokines (pg/ $\mathrm{ml})$.

M: Male; F: female; W: white; B: black; MUL: mulatto; L: localized; G: generalized; +: positive; -: negative; ND: not determined.

\begin{tabular}{cclcccccccc}
\hline Sex & $\begin{array}{c}\text { Age } \\
\text { (years) }\end{array}$ & Race & $\begin{array}{c}\text { Form } \\
\text { of PF }\end{array}$ & $\begin{array}{c}\text { Nikolsky's } \\
\text { sign }\end{array}$ & IL-2 & IL-4 & IL-5 & IL-10 & IL-12 & IFN- \\
\hline M & 10 & W & L & + & 0.00 & 0.00 & 18.62 & 31.62 & 3.24 & 5.58 \\
F & 68 & W & L & + & 10.56 & 0.00 & ND & 24.55 & 4.21 & ND \\
M & 21 & W & L & + & 3.12 & 2.39 & ND & 25.70 & 4.68 & ND \\
M & 15 & MUL & L & + & 0.00 & 0.00 & 18.62 & 19.05 & 2.70 & 2.43 \\
F & 11 & B & G & + & 0.00 & 0.00 & 64.56 & 27.54 & 2.92 & 2.79 \\
F & 27 & MUL & G & + & 0.00 & 0.00 & 7.94 & 30.90 & 2.25 & 5.58 \\
M & 43 & B & G & + & 8.94 & 1.03 & 12.02 & 27.54 & 2.92 & 8.00 \\
M & 35 & W & L & + & 0.00 & 0.63 & 15.13 & 29.51 & 2.25 & 7.37 \\
F & 42 & W & G & + & 0.00 & 0.00 & 18.12 & 22.90 & 2.56 & 5.90 \\
F & 34 & MUL & L & + & 3.89 & 0.26 & 8.71 & 22.90 & 3.42 & 6.78 \\
F & 36 & W & L & + & 0.00 & 0.00 & 6.61 & 24.04 & 1.26 & ND \\
F & 21 & MUL & L & + & 0.00 & 0.00 & 4.90 & 24.04 & 1.56 & 5.90 \\
M & 33 & W & L & - & 3.12 & 0.00 & 4.90 & 19.84 & 1.89 & ND \\
M & 12 & W & L & + & 11.81 & 2.90 & 8.71 & 27.54 & 3.80 & 12.14 \\
F & 31 & MUL & L & + & 1.69 & 1.03 & 8.13 & 22.90 & 2.43 & 7.58 \\
M & 29 & W & L & + & 0.45 & 0.63 & 6.92 & 23.99 & 2.57 & 7.37 \\
F & 25 & W & G & + & 2.43 & 0.63 & 7.41 & 42.66 & 3.26 & 7.79 \\
F & 25 & MUL & L & - & 3.12 & 1.42 & 6.45 & 24.71 & 4.33 & 5.90 \\
M & 61 & W & G & + & 0.00 & 0.00 & 6.02 & 32.35 & 2.23 & 5.14 \\
F & 14 & MUL & L & + & 0.00 & 0.00 & 5.82 & 28.18 & 1.73 & 3.48 \\
F & 29 & W & L & + & 8.94 & 5.54 & 6.92 & 22.91 & 4.21 & 8.95 \\
M & 65 & W & L & + & 1.69 & 0.63 & 8.51 & 35.48 & 3.60 & 8.46 \\
F & 15 & MUL & L & + & 0.00 & 5.54 & 5.13 & 24.76 & 5.33 & 8.00 \\
F & 26 & MUL & L & - & 1.69 & 0.00 & 10.71 & 31.62 & 3.08 & 5.90 \\
M & 23 & W & G & + & 0.45 & 1.48 & 4.90 & 23.99 & 2.74 & 0.74 \\
Median & & & & & 0.45 & 0.26 & 7.94 & 24.76 & 2.92 & 5.90 \\
& & & & & & & & & &
\end{tabular}


respectively for IL-2, and 0.26 and $10.16 \mathrm{pg} /$ $\mathrm{ml}$, respectively for IL-4. The same was observed for IL-5 (7.94 and $15.74 \mathrm{pg} / \mathrm{ml}$, respectively) and IFN- $\gamma$ (5.90 and $8.58 \mathrm{pg} /$ $\mathrm{ml}$, respectively). For IL-10 and IL-12, higher concentrations were observed in PF patients $(\mathrm{P}<0.01)$ compared to controls (IL-10: 24.76 and $20.92 \mathrm{pg} / \mathrm{ml}$; IL-12: 2.92 and $1.17 \mathrm{pg} / \mathrm{ml}$, respectively) (Figure 1).

There was no association $(\mathrm{P}>0.05)$ between cytokine levels and the localized or generalized clinical forms of PF.

\section{Discussion}

Cytokines are small glycopeptides secreted by white cells, T, B and natural killer lymphocytes, macrophages, Langerhans cells or other cell types, which are involved in cell-to-cell communication in response to specific stimuli (8).

T helper lymphocytes $\left(\mathrm{CD}^{+}\right)$can be divided into two different subtypes, Th1 and Th2, depending on which cytokines are predominantly secreted $(9,10)$. These subtypes have been determined in mice as follows: Th1 producing IFN- $\gamma$ and IL-2, and Th2 producing IL-4, IL-5 and IL-10 (11). IL-12 is produced mainly by B lymphocytes, Langerhans cells, and macrophages, and is responsible for the stimulation of the Th1 cytokine profile. On the other hand, IL-10 has the function of inhibiting the Th1 profile $(12,13)$. In human beings, clones of lymphocytes that express cytokines similar to the Th1 and Th2 patterns exist, but there are clones that produce cytokines of both patterns, which have been designated Th0 (14).

Cytokines IL- 2 and IFN- $\gamma$ were decreased in PF, and this could have been caused primarily or secondarily by inhibition of the Th1 profile. IL-10 was increased in PF, probably functioning by stimulating the proliferation of B lymphocytes, being responsible for the larger production of antibodies, including IgG anti-desmoglein I, and inhibiting the Th1 profile. Increased numbers of B lymphocytes could be responsible for the high production of IL-12, explaining its increase in PF patients. Inhibition of the Th2 profile may be caused by IL-12. Since IL-12 was found to be increased in PF, it may have been responsible for decreased serum levels of IL-4 and IL-5. However, it should have stimulated the Th1 response, which was found to be inhibited in this study.

We did not detect an association between cytokine levels and localized or generalized forms of PF. However, this observation is limited by the fact that we may have included patients in different phases of the disease.

There have been reports of participation of IL- 6 and TNF- $\alpha$ in pemphigus vulgaris, and of increased IL-5, IL-6 and IL- 8 in bullous pemphigoid (6,7). Recently, Lin et al. (15) demonstrated an autoimmune $\mathrm{CD} 4^{+} \mathrm{T}$-cell response associated with $\mathrm{PF}$, besides a $\mathrm{Th} 2$ cytokine profile in the supernatant of T-cell clones from 5 patients with PF. Our study suggests that within a Th1/Th2 paradigm, the Th1 profile seems to be inhibited while the Th2 profile predominates in PF. Further

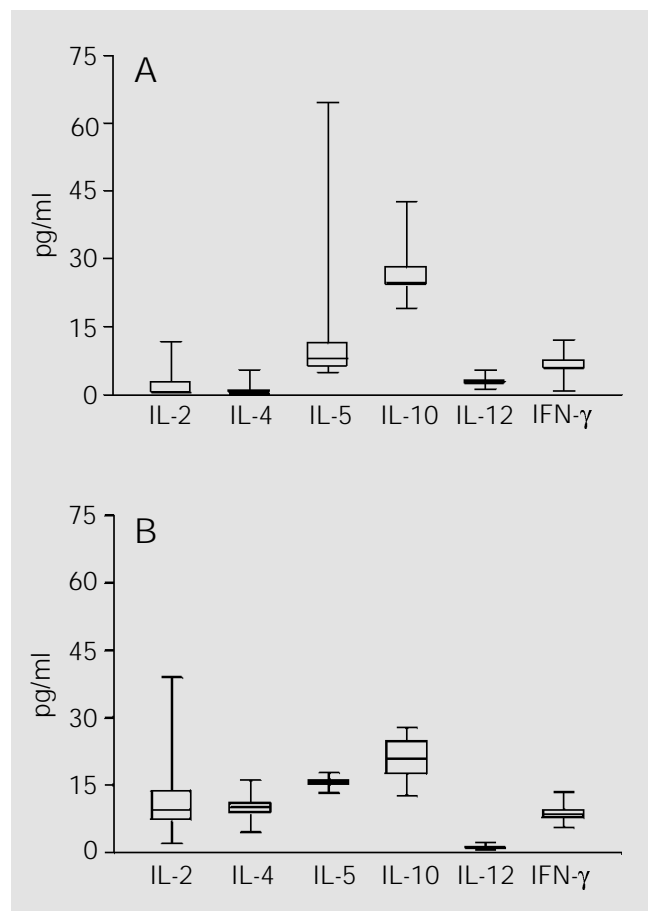

Figure 1 - Serum cytokines (median and $25-75 \%$ range) in patients with Brazilian pemphigus foliaceus (A) and in the healthy control group (B). 
studies with larger numbers of patients with PF will be necessary for a better understand- ing of the immunopathology of this important disease.

\section{References}

1. Cazenave P (1844). Pemphigus chronic, general form rare of pemphigus foliaceus. Annales de Malladie de la Peau, 1: 208210.

2. Beutner EH \& J ordan RE (1964). Demonstration of skin antibodies in sera of pemphigus vulgaris patients by indirect immunofluorescent staining. Proceedings of the Society for Experimental Biology and Medicine, 117: 505-510.

3. Amagai M (1995). Adhesion molecules. I: Keratinocyte-keratinocyte interactions; cadherins and pemphigus. J ournal of Investigative Dermatology, 104: 146-152.

4. Emery DS, Diaz LA, Fairley J Á, Lopez A, Taylor AF \& Giudice GJ (1995). Pemphigus foliaceus and pemphigus vulgaris autoantibodies react with the extracellular domain of desmoglein-1. J ournal of Investigative Dermatology, 104: 323-328.

5. Hashimoto K, Shafran KM, Webber PS, Lazarus S \& Singer KH (1983). Anti-cell surface pemphigus autoantibody stimulates plasminogen activator activity of human epidermal cells. J ournal of Experi- mental Medicine, 157: 259-272.

6. D'Auria L, Bonifati $C$, Mussi $A, D^{\prime}$ Agosto G, De Simone C, Giacalone B, Ferraro C \& Ameglio $F$ (1997). Cytokines in the sera of patients with pemphigus vulgaris: interleukin-6 and tumour necrosis factor-alpha levels are significantly increased as compared to healthy subjects and correlate with disease activity. European Cytokine Network, 8: 383-387.

7. Inaoki M \& Takehara K (1998). Increased serum levels of interleukin (IL)-5, IL-6 and IL-8 in bullous pemphigoid. J ournal of Dermatological Science, 16: 152-157.

8. Mosmann TR (1991). Cytokine secretion patterns and cross-regulation of T cell subsets. Immunologic Research, 10: 183188.

9. Swain $S L$, Weinberg $A D \&$ English $M$ (1990). CD4+ T cell subsets. Lymphokine secretion of memory cells and of effector cells that develop from precursors in vitro. J ournal of Immunology, 144: 17881799.

10. Finkelman FD, Holmes J, Katona IM, Ur- ban J r JF, Beckmann MP, Park LS, Schooley KA, Coffman RL, Mosmann TR $\&$ Paul WE (1990). Lymphokine control of in vivo immunoglobulin isotype selection. Annual Review of Immunology, 8: 303333.

11. Scott P (1993). IL-12: Initiation cytokine for cell-mediated immunity. Science, 260: 496-497.

12. Moore K, O'Garra A, Malefyt R, Vieira P \& Mosmann T (1993). Interleukin-10. Annual Review of Immunology, 11: 165-190.

13. Balter M (1995). Cytokines move from the margins into the spotlight. Science, 268: 205-206.

14. Quesniaux VF (1992). Interleukins 9, 10, 11 and 12 kit legand: a brief overview. Research in Immunology, 143: 385-400.

15. Lin M-S, Fu C-L, Aoki V, Hans-Filho G, Rivitti EA, Moraes J R, M oraes ME, Lazaro AM, Giudice GJ , Stastny P \& Diaz LA (2000). Desmoglein-1-specific T lymphocytes from patients with endemic pemphigus foliaceus (fogo selvagem). J ournal of Clinical Investigation, 105: 207-213. 